\title{
Mini-Review: Syngas Production Via Partial Oxidation of Methane Reaction and Its Potential Catalyst
}

\author{
Silvana D Nurherdiana ${ }^{1}$; Reva E Nugraha ${ }^{1}$; Rachmad R Yogaswara, ${ }^{1}$; Hamzah Fansuri ${ }^{2}$ \\ ${ }^{1}$ Departemen Teknik Kimia, Universitas Pembangunan Nasional "Veteran" Surabaya, Jawa Timur \\ ${ }^{2}$ Department of Chemistry, Institut Teknologi Sepuluh Nopember Surabaya, Jawa Timur \\ *Corresponding author: silvana.dwi.tk@upnjatim.ac.id
}

\begin{abstract}
Methane as a light gas was generally found in natural gas, which was burned freely to gain a high quality of petroleum. This action truly impacted the worst condition in nature, namely the greenhouse effect. This brief review described a fundamental theory of the crucial process in methane conversion from natural gas into value-added chemicals such as syngas $\left(\mathrm{CO}+\mathrm{H}_{2}\right)$. The methane conversion reaction was commonly divided into direct and indirect reactions. The indirect reaction such as partial oxidation of methane was mostly chosen due to the intermediate product (syngas) can easily generate many raw materials of petrochemicals. This paper also described a potential catalyst to be applied in heterogeneous types, such as perovskite oxide, metal oxide, and zeolite.
\end{abstract}

Keywords: methane; syngas; perovskite oxide; catalyst, methane conversion.

\begin{abstract}
Abstrak
Metana sebagai gas ringan umumnya terdapat dalam gas alam yang dibakar secara bebas untuk mendapatkan minyak bumi yang berkualitas tinggi. Tindakan ini benar-benar berdampak pada kondisi alam yang paling buruk yaitu efek rumah kaca. Tinjauan singkat ini menjelaskan teori dasar tentang proses penting dalam konversi metana dari gas alam menjadi bahan kimia bernilai tambah seperti syngas $\left(\mathrm{CO}+\mathrm{H}_{2}\right)$. Reaksi konversi metana secara umum dibagi menjadi reaksi langsung dan tidak langsung. Reaksi tidak langsung seperti oksidasi parsial metana banyak dipilih karena produk antara (syngas) dapat menghasilkan banyak bahan baku petrokimia. Makalah ini juga memaparkan katalis yang berpotensi untuk diaplikasikan yaitu tipe heterogen seperti oksida perovskit, oksida logam dan zeolit.
\end{abstract}

Kata kunci: metana, syngas, oksida perovskite, katalis, konversi metana. 


\section{Introduction}

Indonesia has abundant natural gas reserves which methane as the main component with the $11^{\text {th }}$ largest reserves rank in the world and a reserve to production value $(\mathrm{R} / \mathrm{P})$ of 59 years at a stable price [1]. In addition, natural gas also accounts for about $20 \%$ of long-chain hydrocarbons and nonhydrocarbon gases such as $\mathrm{N}_{2}, \mathrm{CO}_{2}$ and $\mathrm{H}_{2} \mathrm{~S}$ [2]. The highly fuel content in natural gas makes it widely consumed as a source of energy for industry and households.

Although the reserves are in abundant amounts, the use of natural gas is limited by the distribution constraint due to its form is gas. The long-chain hydrocarbon gas component can be compressed into a liquid by applying high pressure known as CNG (Compressed Natural Gas), which makes it easier to control and move. However, its greatest contain is methane, is a gas that can not be compressed so that its use really can only be done in the form of gas. Transport constraints lead to the most effective and efficient utilization only when close to natural gas sources. Based on the description, the increase in the benefits of natural gas will be expanded if methane in natural gas is converted into longer chain hydrocarbons that can be melted and become more value-added petrochemical materials such as polymer, fertilizer and plastic raw materials [3].

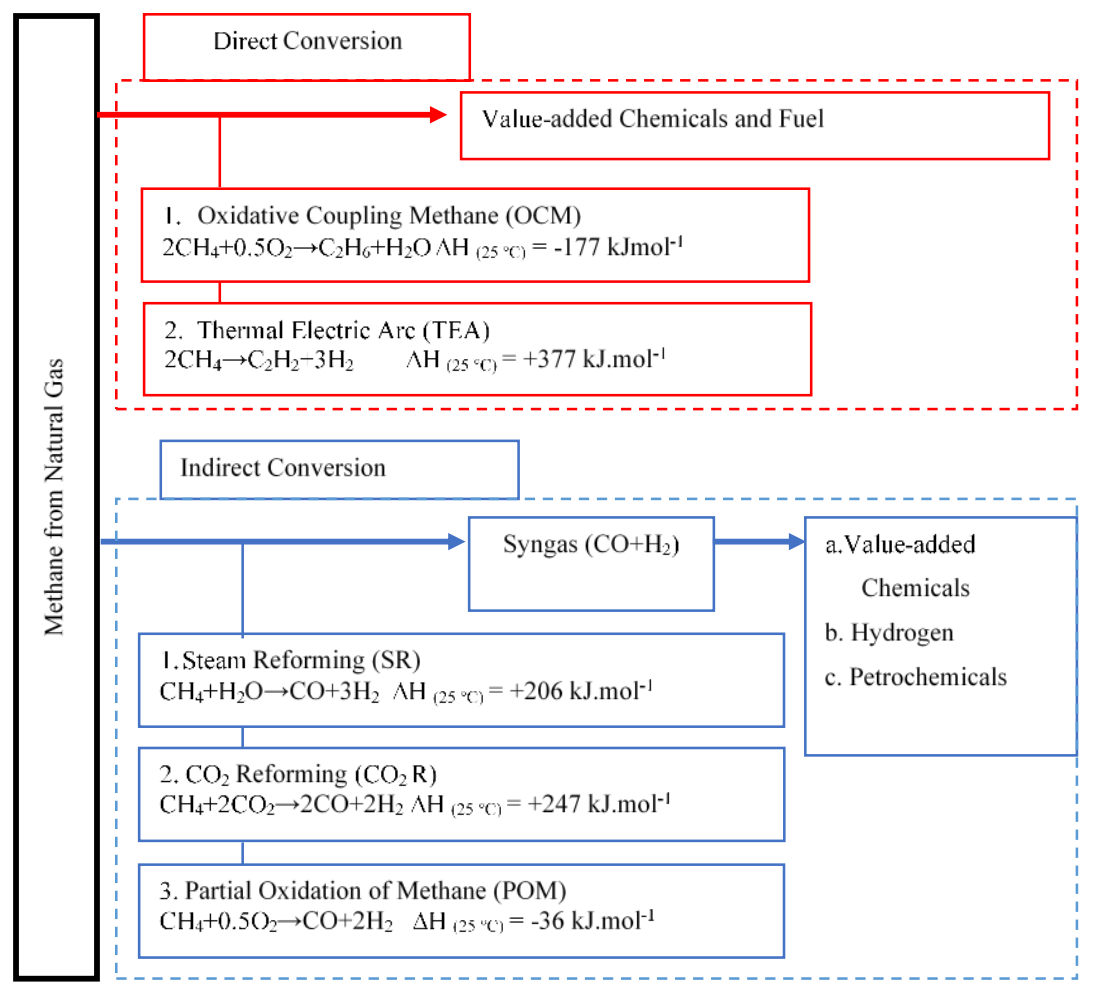

Figure 1. The reaction of Methane Conversion from Natural Gas 
Conversion of methane into longchain hydrocarbons can be converted through the direct and indirect processes as shown in Figure 1. Direct conversion methods such as Oxidative Coupling Methane (OCM) have been studied by Farsi and Mansouri [4] with methane and yield $\left(\mathrm{C}_{2+}\right)$ conversion respectively reaching $45 \%$ and $27 \%$. This value can be achieved in reaction with high temperature and low reaction efficiency kinetically. Another inefficient method is the Thermal Electric Arc (TEA) which requires operation temperatures greater than $2727{ }^{\circ} \mathrm{C}$ from plasma with a power of $10 \mathrm{kWh} . \mathrm{kg}^{-1}$ $\mathrm{C}_{2} \mathrm{H}_{2}[5]$.

Compared to the direct conversion methods, indirect conversions such as Steam Reforming (SR) and $\mathrm{CO}_{2}$ Reforming $\left(\mathrm{CO}_{2} \mathrm{R}\right)$ react in an endothermic condition that requires enormous energy and expensive maintenance costs. Indirect conversion is performed by producing an intermediate product of syngas (mixture of $\mathrm{H}_{2}$ and $\mathrm{CO}$ with ratio 2:1), followed by long-chain hydrocarbon synthesis using the Fischer-Tropsch method with the reaction shown by Eq 1. However, the ratio of $\mathrm{H}_{2}$ :CO generated from the methods of SR and $\mathrm{CO}_{2} \mathrm{R}$ sequentially is 3: 1 and 1: 1 , which do not correspond to the amount of feed required for the Fisher-Tropsch synthesis of 2: 1.

$$
\begin{aligned}
\mathrm{CO}+2 \mathrm{H}_{2} \rightarrow+\mathrm{CH}_{2}-+\mathrm{H}_{2} \mathrm{O} \\
\Delta \mathrm{H}\left(25^{\circ} \mathrm{C}\right)=-152 \mathrm{~kJ} \cdot \mathrm{mol}^{-1}
\end{aligned}
$$

Partial oxidation of methane (POM) also produces syngas with a stoichiometric $\mathrm{H}_{2}: \mathrm{CO}$ of 2:1 which ideal ratio for hydrocarbon production by the FT process and react in an exothermic condition which can reduce $30 \%$ operating costs. In addition, POM reaction can also be performed on a large scale (industrial scale) or small scale (laboratory scale) [6]. The syngas usage for the industry have been much attention as a raw material for methanol industry such as Methanol Bunyu Pertamina and PT Kaltim Methanol Industry with the total production capacity of 990,000 tons per year, PT Sintas Kurama Perdana 11,000 tons per year and imports 3,532,323 tons in 2004 and ammonia industries such as PT Pupuk Kaltim, Kaltim Pacific Ammonia, and PT Kaltim Parna with total production capacity $3,860,000$ tons per year.

Therefore, the development and optimization of the syngas production process become very important to do [7]. The POM reaction, although it has been done with both homogeneous and heterogeneous catalysts which requires a high temperature of 700 to $1,000{ }^{\circ} \mathrm{C}$ to activate four identical $\mathrm{C}$-H bonds. In addition, the oxygen involved in the reaction should not be excessive due to high temperatures and oxygen in excess amounts lead to the complete oxidation of methane into $\mathrm{CO}_{2}$ dan $\mathrm{H}_{2} \mathrm{O}$. Therefore, this article briefly described the fundamental overview of syngas, partial oxidation of methane reaction 
and potential catalyst which involved in optimizing the syngas production

\section{Fundamental Theory of Syngas}

Syngas is an intermediate product of methane conversion reaction, composed of $\mathrm{H}_{2}$ and $\mathrm{CO}$ with a composition ratio of 2:1 [8]. Hereinafter, Table 1 describes the following characteristics of $\mathrm{H}_{2}$ and $\mathrm{CO}$. Moreover, chemical characteristics can also be known from the molecular structure of $\mathrm{H}_{2}$ and $\mathrm{CO}$. Hydrogen is a non-metallic element, colorless and odorless, binding to form covalent diatomic hydrogen due to the use of electrons together, highly flammable but not emitting pollutants into the environment at standard temperature and pressure. Therefore, hydrogen as the most considerable energy has energy per unit of weight of $120,7 \mathrm{~kJ}^{-\mathrm{g}^{-1}}$ thus recommended as carrier energy in the future [9].

Table 1. $\mathrm{H}_{2}$ and $\mathrm{CO}$ Gas Characteristics

\begin{tabular}{lll}
\hline Characteristics & $\mathrm{H}_{2(\mathrm{~g})}$ & $\mathrm{CO}_{(\mathrm{g})}$ \\
\hline Density $\left(\mathrm{g} . \mathrm{L}^{-1}\right)$ & 0,08988 & 1,250 \\
$\left(0{ }^{\circ} \mathrm{C}, 1 \mathrm{~atm}\right)$ & & \\
Molar mass $\left(\mathrm{g} . \mathrm{mol}^{-1}\right)$ & 2 & 28,0101 \\
Melting point $\left({ }^{\circ} \mathrm{C}\right)$ & $-259,14$ & -205 \\
Boiling point $\left({ }^{\circ} \mathrm{C}\right)$ & $-252,87$ & -192 \\
\hline
\end{tabular}

Source : Harahap and Tjahjono, 2016 [7]

While CO has chemical bonds consisting of two covalent bonds and a coordinate covalent bond with the electron density at $\mathrm{C}$ is higher than $\mathrm{O}$ which introduces a small dipole moment with a small electronegative difference. As a result, the molecular structure can resonate then affects the reactivity to other carbon cations. $\mathrm{CO}$ is colorless, odorless that can produce from incomplete combustion of carbon or methane compound. Despite its toxic and flammable nature, $\mathrm{CO}$ plays a key role as a primary feedstock for chemicals products such as methanol, acetic acid and long-chain hydrocarbon fuels from hydrogenation and the Fischer-tropsch reactions between $\mathrm{CO}$ and $\mathrm{H}_{2}$ [10].

In addition, syngas is also used as fuel gas and produce value-added chemicals as shown in Figure 2 which can be utilized by the petrochemical industry for the raw materials of polymers, textile, fertilizers and farms. Syngas can be obtained basically from the methane conversion process from natural gas and coal. While coal as a raw material produces harmful and toxic emissions during the syngas production process. Thus natural gas has been widely consumed to reduce the risk of global warming. Indonesia is the country with the largest natural gas reserves at 11th place from all over the world and 3rd from Asia-pacific with 99.77 trillion cubic feet (TCF) with a reserve potential of 50.21 TCF [11]. Natural gas sources can be obtained from biomass gasification (biogas) using 
anaerobic bacteria by purification process of water $\left(\mathrm{H}_{2} \mathrm{O}\right)$, hydrogen sulfide $\left(\mathrm{H}_{2} \mathrm{~S}\right)$ and particulate to reach pipeline quality. Besides natural gas from biogas, other sources of natural gas are oil, coal and natural gas fields.
Both sources have the largest methane composition with a number of differences in secondary compositions as shown in Table 2 [12].

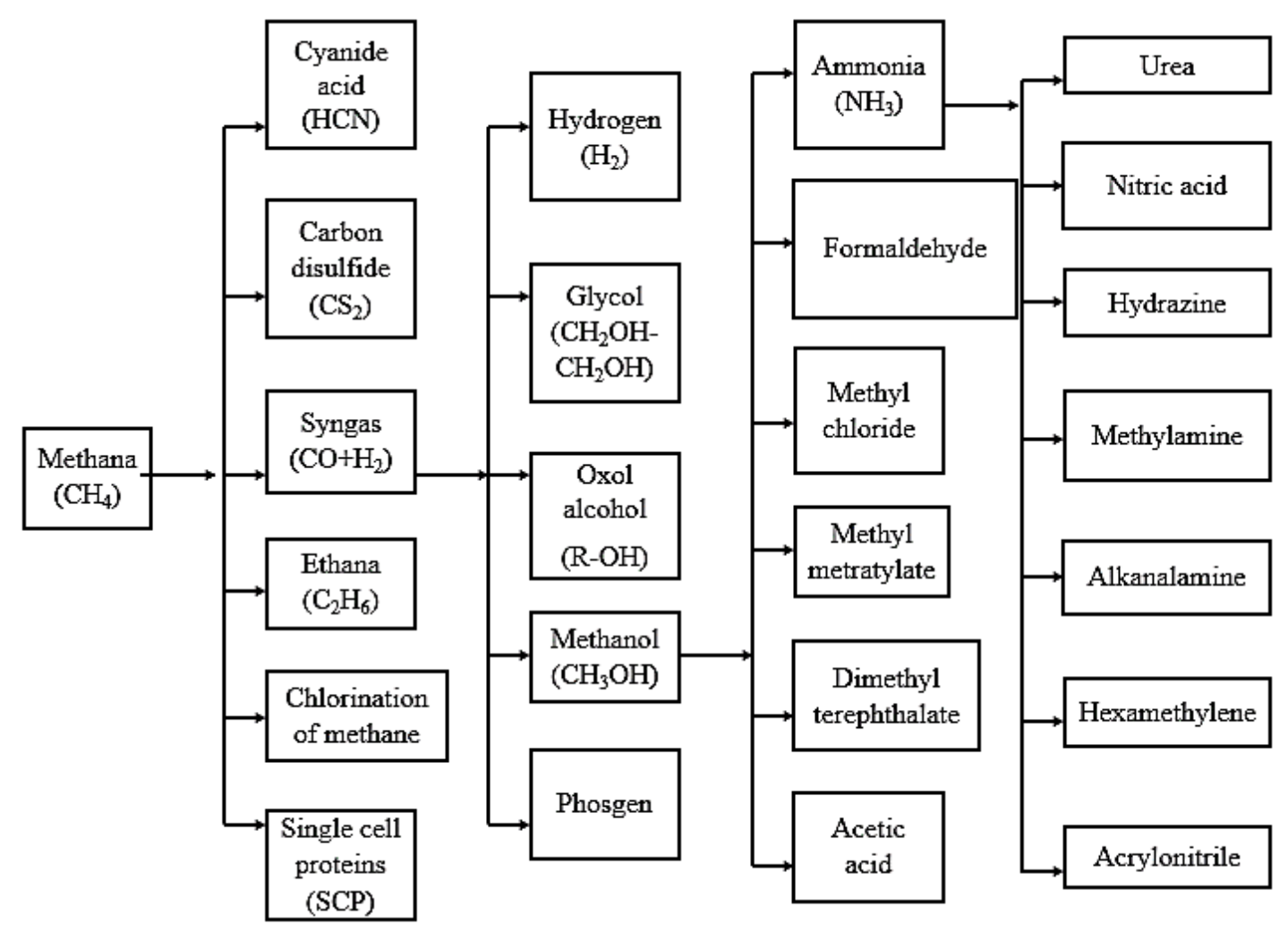

Figure 2. Methane Conversion Products [10].

Meanwhile, the high methane composition in nature has a serious impact in radiation up to 21 times greater than carbon dioxide $\left(\mathrm{CO}_{2}\right)$, greenhouse effect and rising earth temperature. This is because methane is very easy to react photochemically with $\mathrm{OH}$ radicals derived from the reaction between water vapor and ozone $\left(\mathrm{O}_{3}\right)$ in the troposphere so that the amount of $\mathrm{O}_{3}$ decreases [13]. Therefore, natural gas in mining areas contributes the most significant percentage of methane content which is preferably burned to carbon dioxide. 
Table 2. Biogas and Natural Gas Composition

\begin{tabular}{ccc}
\hline \multirow{2}{*}{ Compound } & \multicolumn{2}{c}{ Composition (\%) } \\
\cline { 2 - 3 } & Biogas & Natural gas \\
\hline Methana $\left(\mathrm{CH}_{4}\right)$ & $55-70$ & $60-90 \%$ \\
Carbon dioxide $\left(\mathrm{CO}_{2}\right)$ & $30-40$ & 0,61 \\
Nitrogen $\left(\mathrm{N}_{2}\right)$ & $0-0.3$ & 1 \\
Hydrogen sulfide $\left(\mathrm{H}_{2} \mathrm{~S}\right)$ & $0-3$ & 0.07 \\
Oxygen $\left(\mathrm{O}_{2}\right)$ & $0.1-0.5$ & - \\
Hydrogen $\left(\mathrm{H}_{2}\right)$ & $1-5$ & - \\
Ethane $\left(\mathrm{C}_{2} \mathrm{H}_{6}\right)$ & - & $5-8$ \\
Propane $\left(\mathrm{C}_{3} \mathrm{H}_{8}\right)$ & - & $2-7$ \\
Butane $\left(\mathrm{C}_{4} \mathrm{H}_{10}\right)$ & - & $0,4-3$ \\
Pentane $\left(\mathrm{C}_{5} \mathrm{H}_{12}\right)$ & - & $0,2-5$ \\
\hline
\end{tabular}

On the other hand, natural gas can be utilized as household fuel for large-scale purposes such as industry rather than burned in vain. However, the usage can be utilized directly and close to natural gas sources to maintain the exergy efficiency. However, most of the natural gas reserves are scattered in the offshore areas as seen in Figure 3 of the Natuna, South Sumatra, East Kalimantan, Masela and West Papua which areas are far from residential areas thus requiring consideration of production and maintenance techniques as well as the investment costs for gas-distributing such as a gas pipe.

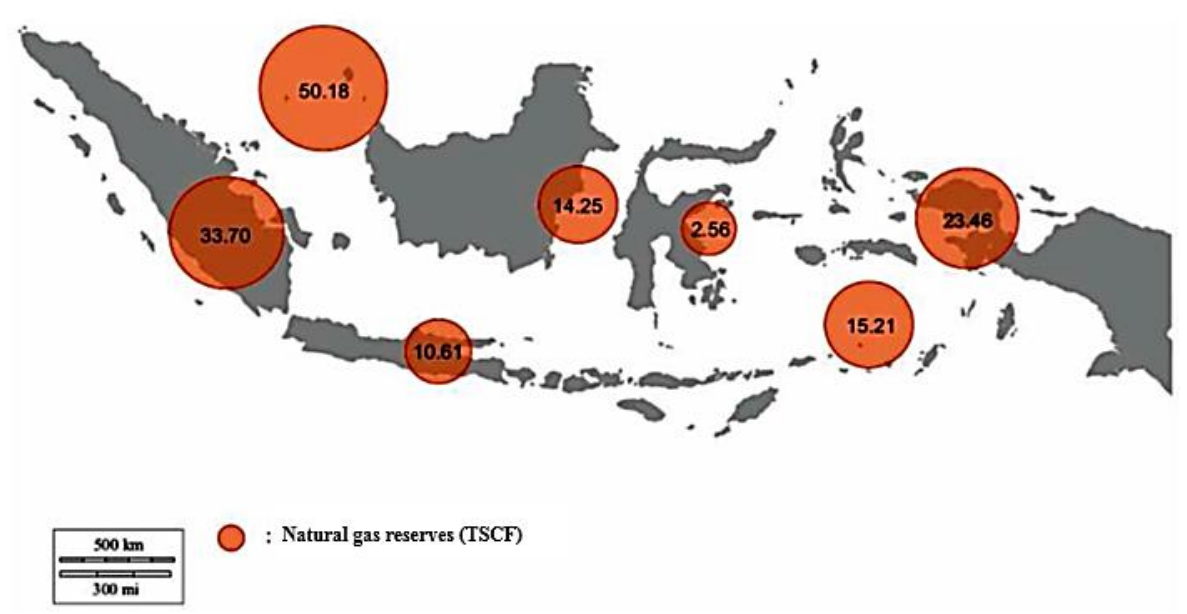

Figure 3. Natural Gas Reserves in Indonesia [11] 
In addition, natural gas reserves in Indonesia increased by $1.5 \%$ from 2004 to 2015 and estimated the reserve values compared to the production of 37.8 [14]. The value-added products from natural gas need to be increased such as chemicals to balance the operating costs of the energy industry. Thus, a process of methane conversion to syngas is essential to be optimized.

\section{Methane Conversion To Syngas Via Partial Oxidation of Methane (POM) Reaction.}

Syngas can be obtained through a methane conversion reaction. In order to the methane conversion process by direct and indirect conversion as mentioned above, the process has each advantage and disadvantages in terms of the operation process and operational costs. As described in Table 3, the syngas production process using POM reaction is mainly recommended to other conventional processes. In addition, POM reaction can be applied on a small scale (laboratory) to large scale such as industrial production to be commercialized [15]. POM reaction occurs exothermic and irreversible which produce $36 \mathrm{~kJ}$ per mole of heat thus the reaction is being considered due to high efficiency of exergy.

Table 3. Methane Conversion Conditions and Results

\begin{tabular}{|c|c|c|c|c|}
\hline $\begin{array}{l}\text { Conversion } \\
\text { methods }\end{array}$ & $\begin{array}{c}\text { Temperature } \\
\left({ }^{\circ} \mathbf{C}\right)\end{array}$ & $\begin{array}{c}\Delta \mathbf{H}_{\left(25^{\circ} \mathrm{C}\right)} \\
\left(\mathbf{k J . m o l}{ }^{-}\right. \\
\text {1) }\end{array}$ & Performance & Ref \\
\hline OCM & $650-950$ & -177 & $\mathrm{C}_{2}$ Selectivity $70-90 \%$ & [16] \\
\hline TEA & $727-2727$ & +377 & Acetylene Selectivity $70-80 \%$ & {$[5]$} \\
\hline SR & $625-750$ & +206 & Ratio of $\mathrm{H}_{2} / \mathrm{CO}=2-3$ & [17] \\
\hline $\mathrm{CO}_{2} \mathrm{R}$ & 700 & +247 & High resistancy on carbon deposition & [18] \\
\hline POM & $600-950$ & -36 & $\begin{array}{l}\mathrm{CH}_{4} \text { Conversion: } 98 \% \text { dan CO Selctivity: } \\
97.5 \%\end{array}$ & [19] \\
\hline
\end{tabular}

POM reaction is imperfection combustion due to involving only half of the amount of oxygen by the reaction in Eq. 2 as follows.

$$
\begin{aligned}
& \mathrm{CH}_{4}+0,5 \mathrm{O}_{2} \rightarrow \mathrm{CO}+2 \mathrm{H}_{2}, \\
& \Delta \mathrm{H}_{25^{\circ} \mathrm{C}}^{0}=-36 \mathrm{kj} \cdot \mathrm{mol}^{-1}
\end{aligned}
$$

Another advantage of the POM reaction is the lower reactor heat which consumes lower operational cost and $\mathrm{H}_{2}$ :CO ratio production of about 2 which can be used in the FischerTropsch process. However, a combustion reaction also occurs when methane reacts with 
oxygen because lower exothermic value as shown in Eq. 3 [20].

$$
\begin{aligned}
\mathrm{CH}_{4}+2 \mathrm{O}_{2} \leftrightarrow \mathrm{CO}_{2}+2 \mathrm{H}_{2} \mathrm{O}, \\
\Delta \mathrm{H}_{25^{\circ} \mathrm{C}}^{0}=-802,3 \mathrm{~kJ} \cdot \mathrm{mol}^{-1}(3)
\end{aligned}
$$

Furthermore, excess methane will react with vapor endothermically through the steam reforming process. This combination of POM and SR reaction will make the process energy more efficient by the reaction shown in the following equations [2] :

$$
\begin{aligned}
& \mathrm{CH}_{4}+\mathrm{H}_{2} \mathrm{O} \leftrightarrow \mathrm{CO}+3 \mathrm{H}_{2} \\
& \mathrm{CH}_{4}+2 \mathrm{H}_{2} \mathrm{O} \leftrightarrow \mathrm{CO}_{2}+3 \mathrm{H}_{2}
\end{aligned}
$$

Followed by water gas shift reaction:

$$
\mathrm{CO}+\mathrm{H}_{2} \mathrm{O} \leftrightarrow \mathrm{CO}_{2}+\mathrm{H}_{2}
$$

And $\mathrm{CO}_{2} \mathrm{R}$ reaction to form syngas:

$$
\mathrm{CH}_{4}+\mathrm{CO}_{2} \leftrightarrow 2 \mathrm{CO}+2 \mathrm{H}_{2}
$$

The selectivity of syngas can be reduced due to the carbon deposition formation which increases the deactivation of the catalytic site of the catalyst by the following Boudouard reaction:

$$
\begin{aligned}
& \mathrm{CO} \leftrightarrow \mathrm{C}+\mathrm{CO}_{2} \\
& \mathrm{CH}_{4} \leftrightarrow \mathrm{C}+2 \mathrm{H}_{2}
\end{aligned}
$$

The carbon fraction can be gasified by heating or oxygen by the reaction:

$$
\begin{aligned}
& \mathrm{C}+\mathrm{H}_{2} \mathrm{O} \leftrightarrow \mathrm{CO}+\mathrm{H}_{2} \\
& \mathrm{C}+\mathrm{O}_{2} \leftrightarrow \mathrm{CO}_{2}
\end{aligned}
$$

Therefore, the major product of syngas can be obtained by particularly control of the $\mathrm{O}_{2}: \mathrm{CH}_{4}$ ratio as feedstock and the temperature conditions more than $1000{ }^{\circ} \mathrm{C}$ with a very short thermodynamic contact time. In addition, the catalyst can be used to control syngas production such as metal oxides, zeolites and perovskite oxides [21].

\section{Active Catalyst Systems for Pom Reaction}

As mentioned before, the catalyst plays an important role in the exergy efficiency of POM reaction and optimization of the methane conversion process as well as the selectivity of syngas. Some mostly recommended catalysts are metal oxides, zeolites and perovskite oxides which have different catalytic performances as shown in Table 4

The metal from metal oxides catalysts is derived from two types: noble metal catalyst (Rh, Ru, Pt, Pd, Ir) and non-noble metal catalysts (Ag, Pt, Ni, Co) [25]. The noble metal catalyst has higher catalytic activity and is hardly poisoned by carbon deposition compared to a non-noble metal catalyst. According to an economical subject, nonnoble metals are more economic and widely recommended in the industry [27] 
Table 4. Metal Oxide, Zeolite and Perovskite Catalyst for Partial Oxidation of Methane

\begin{tabular}{|c|c|c|c|c|c|c|}
\hline \multirow[t]{2}{*}{ Catalyst } & \multirow[t]{2}{*}{$\begin{array}{l}\text { Temperature } \\
\left({ }^{\circ} \mathbf{C}\right)\end{array}$} & \multirow[t]{2}{*}{$\begin{array}{l}\text { Time } \\
\text { (h) }\end{array}$} & \multirow{2}{*}{$\begin{array}{l}\mathrm{CH}_{4} \\
\text { Conversion } \\
(\%)\end{array}$} & $\begin{array}{l}\text { Syng } \\
\text { Selec } \\
(\%)\end{array}$ & s ivity & \multirow[t]{2}{*}{ Ref } \\
\hline & & & & $\mathbf{H}_{2}$ & $\mathrm{CO}$ & \\
\hline $\mathrm{Ni} / \mathrm{Al}_{2} \mathrm{O}_{3}$ & 900 & - & 80 & - & 90 & {$[22]$} \\
\hline $\mathrm{Ni} / \mathrm{MgO}$ & 750 & 100 & 91.2 & 96.3 & 92.4 & {$[23]$} \\
\hline $\mathrm{Ni}-\mathrm{Mg} / \mathrm{Al}_{2} \mathrm{O}_{3}$ & 800 & - & 96.5 & 94 & 95 & [24] \\
\hline $\mathrm{NiO}(75)-\mathrm{Al}_{2} \mathrm{O}_{3}$ & 650 & 25 & 65 & 80 & 70 & [25] \\
\hline Ni/zeolit Y & 700 & 89.6 & - & 88.7 & & [26] \\
\hline Mesopori $\mathrm{NiO}-\mathrm{Al}_{2} \mathrm{O}_{3}$ & 600 & 40 & 80 & 76 & 95 & [27] \\
\hline Ni-zeolit BEA & $625-750$ & $4-8$ & $6-7$ & - & $\begin{array}{l}40- \\
50\end{array}$ & [17] \\
\hline $\mathrm{Pt} / 10 \% \mathrm{Rh}$ & 800 & 8 & 28.2 & & 94 & [28] \\
\hline $\mathrm{Pt}-\mathrm{CeO}_{2}$ & 800 & - & 98 & 61 & 48 & [29] \\
\hline $\mathrm{Ag} / \mathrm{CGA}$ & 600 & - & 23.4 & - & 94 & {$[30]$} \\
\hline $\mathrm{La}_{0.6} \mathrm{Ca}_{0.4} \mathrm{Fe}_{0.75} \mathrm{Co}_{0.25} \mathrm{O}_{3-\delta}$ & 900 & 1400 & 99 & - & 83 & {$[31]$} \\
\hline $\mathrm{La}_{0.6} \mathrm{Sr}_{0.4} \mathrm{Ti}_{0.3} \mathrm{Fe}_{0.9} \mathrm{O}_{3-\delta}$ & 900 & 10 & 60 & - & 99.9 & $\begin{array}{l}{[32],} \\
{[33]}\end{array}$ \\
\hline
\end{tabular}

Nickel catalyst has high catalytic activity and resistance to carbon deposition due to the presence of supporting material to reduce the potential for deactivation as well as membrane leakage of high operational temperature. Mostly, nickel catalyst is easily obtained from $\mathrm{NiO}$ as metal oxide or nitrate compound

$$
\begin{aligned}
2 \mathrm{NiO}+\frac{1}{2} \mathrm{CH}_{4(\mathrm{~g})} & \rightarrow 2 \mathrm{Ni}+\frac{1}{2} \mathrm{CO}_{2(\mathrm{~g})}+\mathrm{H}_{2} \mathrm{O}_{(\mathrm{g})} \\
\mathrm{Ni}+\mathrm{CH}_{4(\mathrm{~g})} & \rightarrow \mathrm{CH}_{\mathrm{x}(\mathrm{s})}+(4-\mathrm{x}) \mathrm{H}_{(\mathrm{s})} \\
\mathrm{CH}_{\mathrm{x}(\mathrm{s})} & \rightarrow \mathrm{C}_{(\mathrm{s})}+\mathrm{xH}_{(\mathrm{s})}
\end{aligned}
$$




$$
\begin{aligned}
\mathrm{H}_{(\mathrm{s})}+\mathrm{H}_{(\mathrm{s})} & \rightarrow \mathrm{H}_{2(\mathrm{~g})}+2 \mathrm{Ni} \\
\mathrm{C}_{(\mathrm{s})}+\mathrm{NiO} & \rightarrow \mathrm{Ni}+\mathrm{CO}_{(\mathrm{s})} \\
\mathrm{CO}_{(\mathrm{s})}+\mathrm{NiO} & \rightarrow \mathrm{CO}_{2(\mathrm{~s})}+\mathrm{Ni} \\
\mathrm{CO}_{2(\mathrm{~s})} & \rightarrow \mathrm{CO}_{2(\mathrm{~g})}+\mathrm{Ni} \\
2 \mathrm{H}_{(\mathrm{s})}+\mathrm{NiO} & \rightarrow \mathrm{H}_{2} \mathrm{O}_{(\mathrm{g})}+\mathrm{Ni}
\end{aligned}
$$

Compared to the reaction in equation (13), reaction (12) is more difficult to react thus a pre-treatment process is essentially required to activate the catalyst active site such as flowing $\mathrm{H}_{2}$ at $500{ }^{\circ} \mathrm{C}$ for an hour to reduce metal oxide into metal or the other treatment usage of carrying out the POM reaction at a temperature above $800{ }^{\circ} \mathrm{C}$. This is because the metal oxide catalyst is only active in oxidation number of 0 then actives the $\mathrm{CH}_{4}$ to produce $\mathrm{CO}, \mathrm{H}_{2}$ and $\mathrm{CO}_{2}$. The characteristics also apply to other metal oxide catalysts which are activated only in a metal form such as Rh, Pt and Co [[34], [35]].

In addition to metal oxide, the zeolite may also act as a POM reaction catalyst and good catalyst support simultaneously since the nickel catalyst is less dispersed on a metal oxide support. Zeolite has been widely applied as a heterogeneous catalyst because it has a regular pore structure, high surface area and acidic properties. These advantages make zeolites have a higher methane conversion of $94 \%$ and $\mathrm{H}_{2}$ selectivity of $93 \%$ than metal oxide as a catalyst supporter [[26]]. As stated in some previous research, suitable zeolite can be used as a POM reaction catalyst. They are ZSM5, Zeolite Y, mordenite and BEA zeolite. The catalysts have a surface area between 400 to $800 \mathrm{~m}^{2} \cdot \mathrm{g}^{-1}$ which Ni easily dispersed well. Moreover, the acid side increased the toxicity resistance such as $\mathrm{CO}_{2}$ that able to deactivate the catalyst [36].

The catalyst usage can be adjusted to decrease the reactor heating temperature, carbon deposition as well as can control the feed for POM reaction to syngas. The use of environmental air as an oxygen supply can improve efficiency because the use of pure oxygen operationally increases the risk of fire and excessive heat which also increases operational cost. However, the content of $70 \%$ of the air is nitrogen while the separation between nitrogen and oxygen is not easy [[20]]. In 1985 Tereoka et al introduced perovskite as an ionic and electronic conductor that continues to be applied as a solid oxide fuel cell (SOFC) to a methane conversion catalyst such as POM reaction. As aforementioned, oxygen does not diffuse through the pore but rather the oxygen lattice in the perovskite structure [37]. 
Currently, heterogeneous catalysts are widely studied in the form of metal oxides, zeolites and perovskites. Metal oxides used include $\mathrm{Al}_{2} \mathrm{O}_{3}, \mathrm{NiO}, \mathrm{CeO}_{2}$ dan some other transition metal oxides [[26], [38], [39]]. Some researchers suggest that the use of zeolite catalysts with large surface area and mesoporous such as ZSM-5, zeolite $\mathrm{Y}$ and zeolite A introduced good catalytic activity [[26], [36]]. However, neither metal oxide nor zeolite catalysts can control the oxygen involved in POM reaction.

The disadvantages can be overcome by the use of membranes which are selectively oxygen ion-conducting agents, in which one of the materials that can be used is perovskite oxide. Oxygen supply for POM comes from perovskite lattice oxygen and the amount of oxygen that can be provided depends on the type of perovskite oxide, its membrane thickness, reaction temperature and pressure [40]. Given the extreme reaction conditions (high temperature and pressure), the usable oxygen ion-conducting membrane needs to include the criteria as shown in Figure 1

One of the perovskite oxide membranes which has a general arrangement of $\mathrm{ABO}_{3}$ and high oxygen permeation is Cobased as $\mathrm{LaCoO}_{3-\delta}$ which was first studied by Teraoka et al [37]. In an effort to increase the conductivity of ions and electrons, each side of $\mathrm{A}$ can be substituted ions $\mathrm{Ba}^{2+}$ and/or $\mathrm{Sr}^{2+}$ while the $\mathrm{B}$ side is $\mathrm{Fe}^{\mathrm{n}+}$ and/or $\mathrm{Co}^{4+}$. However, both $\mathrm{Ba}^{2+}$ and $\mathrm{Sr}^{2+}$ easily react with $\mathrm{CO}_{2}$ to form $\mathrm{BaCO}_{3}$ and $\mathrm{SrCO}_{3}$ thereby potentially producing a high carbon deposition [[41], [42]]. The substitution of $\mathrm{Co}^{4+}$ by $\mathrm{Fe}^{3+}$ as in $\mathrm{SrCo}_{0.8} \mathrm{Fe}_{0.2} \mathrm{O}_{3 \delta} \quad$ produces membrane performance with oxygen permeation of 3.1 mL.cm ${ }^{-2} \cdot \mathrm{min}^{-1}$ at $850{ }^{\circ} \mathrm{C}$ but low structural and mechanical stability [40]. On the contrary, the substitution of $\mathrm{Sr}^{2+}$ with other metal ions such as $\mathrm{La}^{3+}$ has a higher valence that uneasily reacts with $\mathrm{CO}_{2}$ and improves structural stability but still low oxygen flux [[43], [44]].

In addition to the LSCF $\left(\mathrm{La}_{1-\mathrm{x}} \mathrm{Sr}_{\mathrm{x}} \mathrm{Co}_{1}\right.$ $\left.{ }_{\mathrm{y}} \mathrm{Fe}_{\mathrm{y}} \mathrm{O}_{3}\right)$ group, $\mathrm{LSM}\left(\mathrm{La}_{1-\mathrm{x}} \mathrm{Sr}_{3} \mathrm{MnO}_{3}\right)$ is also extensively studied for POM reaction due to both structure materials are able to initiate the lattice oxygen to active the $\mathrm{CH}_{4}$ [[45]]. The oxygen ion conductivity of LSM membrane at $900{ }^{\circ} \mathrm{C}$ is $10^{-7} \mathrm{~S} \mathrm{~cm}^{-1}$, which is lower than

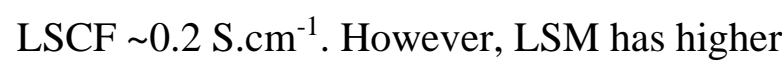
reduction activity of $\mathrm{O}_{2}$ with an electron conductor of $300{\mathrm{~S} . \mathrm{cm}^{-1}}^{-}$than LSCF of 230 ${\mathrm{S} . \mathrm{cm}^{-1}}^{\text {[46]. Therefore, many researchers }}$ develop LSCF and LSM-based perovskite oxides, particularly $\mathrm{La}_{0.7} \mathrm{Sr}_{0.3} \mathrm{Co}_{0.2} \mathrm{Fe}_{0.8} \mathrm{O}_{3}$ and $\mathrm{La}_{0.7} \mathrm{Sr}_{0.3} \mathrm{MnO}_{3}$ as the potential catalyst for methane conversion, primarily on syngas production. 


\section{Conclusion}

Partial oxidation of methane (POM) reaction has been studied as a favorable reaction to produce syngas $\left(\mathrm{CO}+\mathrm{H}_{2}\right)$. However, there were several challenges in the reaction condition such as catalyst usage, effective temperature and pressure to maintain the controlled oxygen reaction with methane. It is due to the high stability of carbon and hydrogen bonding in methane which easily initiates the $\mathrm{CO}_{2}$ and carbon deposition formation while the presence of oxygen $\left(\mathrm{O}_{2}\right)$ in the methane conversion reaction. The heterogeneous catalyst has been developed to solve the problems and contributes significant promising results, such as perovskite oxide which is based on the presence of oxygen vacancy in the crystal structure. The studies indicate the different content on the ionic metal in sites A and B of perovskite revealed significant effects on the performance, especially ionic and electronic conductivity at different temperatures. Nevertheless, a low operating temperature and optimal condition in modified perovskite oxide and the use of other catalysts need to be approached to enhance the commercialization.

\section{Acknowledgment}

The authors would like to thank Dana Internal UPN “Veteran” Jawa Timur Tahun Anggaran 2021 from DIPA UPNVJT with contract number SPP/13/UN.63.8

/LT/IV/2021 for the financial support.

\section{References}

[1] H. M. Syukur, "Potensi gas alam di Indonesia," Forum Teknol., vol. 06, no. 1, pp. 64-73, 2015.

[2] A. P. E. York, T. Xiao, and M. L. H. G. $\tilde{A}$, "Brief overview of the partial oxidation of methane to synthesis gas," Top. Catal., vol. 22, no. April, pp. 345358, 2003.

[3] S. O. Fakayode, B. S. Mitchell, and D. A. Pollard, "Determination of boiling point of petrochemicals by gas chromatography-mass spectrometry and multivariate regression analysis of structural activity relationship," Talanta, vol. 126, pp. 151-156, 2014.

[4] A. Farsi and S. S. Mansouri, "Influence of nanocatalyst on oxidative coupling, steam and dry reforming of methane: A short review," Arab. J. Chem., vol. 9, pp. S28S34, 2016.

[5] H. S. Kang et al., "Methane to acetylene conversion by employing cost-effective low-temperature arc," Fuel Process. Technol., vol. 148, pp. 209-216, 2016.

[6] F. Pohlmann and A. Jess, "Interplay of reaction and pore diffusion during cobaltcatalyzed Fischer-Tropsch synthesis with CO2-rich syngas," Catal. Today, vol. 275, pp. 172-182, 2016.

[7] M. E. Harahap and E. W. Tjahjono, "Kajian Teknologi Proses Pembuatan Gas Sintetik Dari Batubara dan Prospek Pemanfaatan Pada Industri Hilirnya," Maj. Ilm. Pengkaj. Ind., vol. 10, no. 1, pp. 61-70, 2016. 
[8] K. Göransson, U. Söderlind, J. He, and W. Zhang, "Review of syngas production via biomass DFBGs," Renew. Sustain. Energy Rev., vol. 15, no. 1, pp. 482-492, 2011, doi: 10.1016/j.rser.2010.09.032.

[9] A. Haryanto, S. Fernando, N. Murali, and S. Adhikari, "Current Status of Hydrogen Production Techniques by Steam Reforming of Ethanol: A Review," no. 11, pp. 2098-2106, 2005.

[10] A. S. Nasution, A. Haris, and L. Herlina, "Gas Bumi untuk Bahan Bakar Gas dan Bahan Baku Petrokimia," Lembaran Publ. Miny. dan Gas Bumi, vol. 45, no. 2, pp. 139-144, 2011.

[11] W. W. Purwanto, Y. Muharam, Y. W. Pratama, D. Hartono, H. Soedirman, and R. Anindhito, "Status and outlook of natural gas industry development in Indonesia," J. Nat. Gas Sci. Eng., 2015.

[12] Y. Qian, S. Sun, D. Ju, X. Shan, and X. $\mathrm{Lu}$, "Review of the state-of-the-art of biogas combustion mechanisms and applications in internal combustion engines," Renew. Sustain. Energy Rev., vol. 69, no. September 2016, pp. 50-58, 2017.

[13] A. M. Fiore, D. J. Jacob, B. D. Field, D. G. Streets, S. D. Fernandes, and C. Jang, "Linking ozone pollution and climate change: The case for controlling methane," Geophys. Res. Lett., vol. 29, no. 19, pp. 25-1-25-4, 2002, doi: 10.1029/2002GL015601.

[14] BP Statistical Review of World Energy, "BP Statistical Review of World Energy," BP Stat. Rev. World Energy, pp. $1-48,2016$.

DOI: http://dx.doi.org/10.12962/j25493736.v6i2.10720
[15] B. C. Enger, R. L. Lødeng, and A. Holmen, "Modified cobalt catalysts in the partial oxidation of methane at moderate temperatures," J. Catal., vol. 262, no. 2, pp. 188-198, 2009.

[16] Y. Zeng, Y. S. Lin, and S. L. Swartz, "Perovskite-type ceramic membrane: synthesis, oxygen permeation and membrane reactor performance for oxidative coupling of methane," J. Memb. Sci., vol. 150, no. 1, pp. 87-98, 1998.

[17] I. Rossetti et al., "Syngas production via steam reforming of bioethanol over Ni-BEA catalysts: A BTL strategy," Int. J. Hydrogen Energy, vol. 41, no. 38, pp. 16878-16889, 2016.

[18] S. He et al., "Ni/SiO ${ }_{2}$ Catalyst Prepared with Nickel Nitrate Precursor for Combination of $\mathrm{CO}_{2}$ Reforming and Partial Oxidation of Methane: Characterization and Deactivation Mechanism Investigation," J. Nanomater., vol. 2015, pp. 1-8, 2015.

[19] E. G. Babakhani, J. Towfighi, Z. Taheri, A. N. Pour, M. Zekordi, and A. Taheri, "Partial oxidation of methane in $\mathrm{Ba}_{0.5} \mathrm{Sr}_{0.5} \mathrm{Co}_{0.8} \mathrm{Fe}_{0.1} \mathrm{Ni}_{0.1} \mathrm{O}_{3-\delta} \quad$ ceramic membrane reactor," J. Nat. Gas Chem., vol. 21, no. 5, pp. 519-525, 2012.

[20] A. M. De Groote and G. F. Froment, "Simulation of the catalytic partial oxidation of methane to synthesis gas," Appl. Catal. A Gen., vol. 138, no. 2, pp. 245-264, 1996.

[21] B. C. Enger, R. Lødeng, and A. Holmen, "Evaluation of reactor and catalyst performance in methane partial oxidation over modified nickel catalysts," Appl. Catal. A Gen., vol. 364, no. 1-2, pp. 15-26, 2009. 
[22] D. Dissanayake, M. P. Rosynek, K. C. C. Kharas, and J. H. Lunsford, "Partial Oxidation of Methane to Carbon Monoxide and Hydrogen over a Ni/AI203 Catalyst," J. Catal., vol. 132, pp. 117127, 1991.

[23] S. Tang, J. Lin, and K. . Tan, "Partial oxidation of methane to syngas over $\mathrm{Ni} / \mathrm{MgO}, \mathrm{Ni} / \mathrm{CaO}$ and $\mathrm{Ni} / \mathrm{CeO}_{2}$, , Catal. Letters, vol. 51, pp. 169-175, 1998.

[24] K. M. Lee and W. Y. Lee, "Partial oxidation of methane to syngas over calcined Ni-Mg/Al layered double hydroxides," Catal. Letters, vol. 83, no. 1-2, pp. 65-70, 2002.

[25] Y. Kobayashi et al., "Effect of $\mathrm{NiO}$ content in mesoporous $\mathrm{NiO}-\mathrm{Al}_{2} \mathrm{O}_{3}$ catalysts for high pressure partial oxidation of methane to syngas," Appl. Catal. A Gen., vol. 395, no. 1-2, pp. 129 137 , 2011 ,

doi: 10.1016/j.apcata.2011.01.034.

[26] A. Mosayebi and R. Abedini, "Partial oxidation of butane to syngas using nanostructure $\mathrm{Ni} /$ zeolite catalysts," J. Ind. Eng. Chem., vol. 20, no. 4, pp. 1542 1548, 2014.

[27] C. Ding et al., "One step synthesis of mesoporous $\mathrm{NiO}$ - $\mathrm{Al} 2 \mathrm{O} 3$ catalyst for partial oxidation of methane to syngas: The role of calcination temperature," FUEL, vol. 162, pp. 148-154, 2015.

[28] K. Hofstad, T. Sperle, O. Rokstad, and A. Holmen, "Partial oxidation of methane to synthesis gas over a Pt/10\% Rh gauze," Catal. Letters, vol. 45, pp. 97-105, 1997, doi: 10.1023/A:1019030604516.

[29] W. Tang, Z. Hu, M. Wang, G. D. Stucky, H. Metiu, and E. W. McFarland,
"Methane complete and partial oxidation catalyzed by Pt-doped $\mathrm{CeO}_{2}$," J. Catal., vol. 273, no. 2, pp. 125-137, 2010.

[30] E. Ruiz-Trejo, P. Boldrin, J. L. Medley-Hallam, J. Darr, A. Atkinson, and N. P. Brandon, "Partial oxidation of methane using silver/gadolinia-doped ceria composite membranes," Chem. Eng. Sci., vol. 127, pp. 269-275, 2015.

[31] S. Diethelm, J. Sfeir, F. Clemens, J. Van herle, and D. Favrat, "Planar and tubular perovskite-type membrane reactors for the partial oxidation of methane to syngas," J. Solid State Electrochem., vol. 8, no. 9, pp. 611-617, 2004.

[32] A. Tomita, J. Nakajima, and T. Hibino, "Direct oxidation of methane to methanol at low temperature and pressure in an electrochemical fuel cell," Angew. Chemie - Int. Ed., vol. 47, no. 8, pp. 1462 1464, 2008, doi: 10.1002/anie.200703928.

[33] Y. Takahashi, A. Kawahara, T. Suzuki, M. Hirano, and W. Shin, "Perovskite membrane of $\mathrm{La}_{1-\mathrm{x}} \mathrm{Sr}_{\mathrm{x}} \mathrm{Ti}_{1}$ ${ }_{\mathrm{y}} \mathrm{Fe}_{\mathrm{yO} 3-\mathrm{d}}$ for partial oxidation of methane to syngas," Solid State Ionics, vol. 181, no. 5-7, pp. 300-305, 2010, doi: 10.1016/j.ssi.2010.01.008.

[34] C. T. Au and H. Y. Wang, "Pulse study of methane partial oxidation to syngas over $\mathrm{SiO}_{2}$-supported nickel catalysts," Catal. Letters, vol. 41, pp. 159-163, 1996.

[35] C. T. Au, Y. H. Hu, and H. I. Wan, "Pulse studies of $\mathrm{CH}_{4}$ interaction with $\mathrm{NiO} / \mathrm{Al}_{2} \mathrm{O}_{3}$ catalysts," Catal. Letters, vol. 27, pp. 199-206, 1994. 
[36] Y. K. Krisnandi, B. A. P. Putra, M. Bahtiar, I. Abdullah, and R. F. Howe, "Partial Oxidation of Methane to Methanol over Heterogeneous Catalyst Co/ZSM-5," Procedia Chem., vol. 14, pp. 508-515, 2015.

[37] N. Y. Y. Teraoka, H.M. Zhang, S. Furukawa, "Oxygen permeation through pervoskite-type oxides," Chem. Lett., no. C, pp. 1743-1746, 1985.

[38] P. J. S. Prieto, A. P. Ferreira, P. S. Haddad, D. Zanchet, and J. M. C. Bueno, "Designing Pt nanoparticles supported on $\mathrm{CeO}_{2}-\mathrm{Al}_{2} \mathrm{O}_{3}$ : Synthesis, characterization and catalytic properties in the steam reforming and partial oxidation of methane," J. Catal., vol. 276, no. 2, pp. 351-359, 2010.

[39] V. D. Sokolovskii, N. J. Coville, A. Parmaliana, I. Eskendirov, and $\mathrm{M}$. Makoa, "Methane Partial Oxidation. Challenge and Perspective," Catal. Today, vol. 42, no. 3, pp. 191-195, 1998.

[40] H. Pan, L. Li, X. Deng, B. Meng, X. Tan, and K. Li, "Improvement of oxygen permeation in perovskite hollow fibre membranes by the enhanced surface exchange kinetics," J. Memb. Sci., vol. 428, pp. 198-204, 2013.

[41] X. Tan, Z. Pang, and K. Li, “Oxygen production using $\mathrm{La}_{0.6} \mathrm{Sr}_{0.4} \mathrm{Co}_{0.2} \mathrm{Fe}_{0.8} \mathrm{O}_{3-\delta}$ (LSCF) perovskite hollow fibre membrane modules," J. Memb. Sci., vol. 310, no. 1-2, pp. 550-556, 2008.

[42] D. D. Athayde et al., "Review of perovskite ceramic synthesis and membrane preparation methods," Ceram. Int., vol. 42, no. 6, pp. 6555-6571, 2015, doi:

https://doi.org/10.1016/j.ceramint.2016.0 1.130 .

[43] X. Tan, N. Liu, B. Meng, J. Sunarso, K. Zhang, and S. Liu, "Oxygen permeation behavior of $\mathrm{La}_{0.6} \mathrm{Sr}_{0.4} \mathrm{Co}_{0.8} \mathrm{Fe}_{0.2} \mathrm{O}_{3}$ hollow fibre membranes with highly concentrated $\mathrm{CO}_{2}$ exposure," J. Memb. Sci., vol. 389, pp. 216-222, 2012.

[44] H. Wang, Y. Cong, and W. Yang, "Oxygen permeation study in a tubular $\mathrm{Ba}_{0.5} \mathrm{Sr}_{0.5} \mathrm{Co}_{0.8} \mathrm{Fe}_{0.2} \mathrm{O}_{3-} \quad{ }_{\delta} \quad$ oxygen permeable membrane," J. Memb. Sci., vol. 210, no. 2, pp. 259-271, 2002.

[45] I. K. Murwani, S. Scheurell, M. Feist, and E. Kemnitz, "Nanoparticle Synthesis of $\mathrm{La}_{1}{ }_{\mathrm{x}} \mathrm{Sr}_{\mathrm{x}} \mathrm{MnO}$ 3," J. Therm. Anal. Calorim., vol. 69, pp. 9-21, 2002.

[46] S. P. Jiang, "A comparison of $\mathrm{O}_{2}$ reduction reactions on porous $(\mathrm{La}, \mathrm{Sr}) \mathrm{MnO}_{3}$ and $(\mathrm{La}, \mathrm{Sr})(\mathrm{Co}, \mathrm{Fe}) \mathrm{O} \quad 3$ electrodes," Solid State ionics, vol. 146, pp. 1-22, 2002. 